\title{
ORIGINAL
}

\section{Chemistry of Succinimido Esters. XXI ${ }^{* 1}$. Determination of Sphingosine Bases as $N$-Arylacetyl Derivatives by Normal Phase HPLC}

\author{
Hirofumi Hirata, Katsuhiko Higuchi, Takao Yamashina, and Masaaki Sugiura \\ National Chemical Laboratory for Industry \\ (Higashi 1-1, Tsukuba-shi, ₹ 305)
}

A sensitive determination of sphingolipid bases (1) was made using synthetic $\mathrm{C}_{n}$-dihyrosphingosine and naturally occurring $\mathrm{C}_{18}-(1)$ aromatized with $N$-succinimidyl arylacetate ( $\left.2 \mathrm{a}\right)$. The amino group in ( 1 ) easily reacted with ( 2 a) to give the corresponding $N$-arylacetyl derivative ( 3 a). The isomers of $(1)$ were separated on a normal phase HPLC column in the form of $(3 \mathrm{a})$ which was detectable by the absorption in UV region. The isomer content of ( 1 ) as determined by the present method using ( 3 a) having a different substituent showed agreement with that determined by GC method in the form of $\mathrm{N}$-acetyl-O, $\mathrm{O}$-bis (TMS) derivatives of $(1)$ and the HPLC method in the form of $N$-arylcarbonyl derivative of (1), ( $3 \mathbf{b})$.

\section{Introduction}

Analyses of sphingolipid bases (long chain bases) ( 1 ) are generally performed by GC using SE-30, OV-1, and OV-17 columns. The suitable compounds*2 $^{* 2}$ are $\mathrm{N}$-acetyl-O-TMS ${ }^{11}$ and $\mathrm{N}, \mathrm{O}$ TMS $^{21}$ derivatives. $N$-Acyl-O-TMS derivative of $(1)$ is also applicable ${ }^{3)}$. Recently, we reported that the erythro/threo separation and the determination of erythro isomer content of synthetic dihydrosphingosine (DHSph) could be done by normal (in the form of $\mathrm{N}, \mathrm{O}, \mathrm{O}$-triacetyl and $\mathrm{N}$ acetyl derivative ${ }^{4)}$ and reverse (in the form of free bases and their $N$ acetyl derivatives $)^{5)}$ phase HPLC. But, these methods had a disadvantage of low sensitivity even at low detection wavelengths (200 $\sim 220 \mathrm{~nm})$. This problem was overcome by aromatization of

* 1 Chemistry of Succinimido Esters. XX. Yukagaku, 40, 1023 (1991)

*2 Abbreviations

TMS : Trimethylsilyl, DSC : $N, N^{\prime}$ - Disuccinimidyl carbonate, DSO : $N, N^{\prime}$ - Disuccinimidyl oxalate, HMDS : Hexamethyl disilazane, TMCS : Trimethylchlorosilane
DHSph with $N$-succinimidyl benzoate $(2 \mathrm{~b})^{6)}$.

In the previous papers on the reaction of $\mathrm{N}$ succinimidyl arylacetate ( $2 \mathrm{a}$ ) with an amino compound in aqueous solution ${ }^{7)}$, we found out that ( 2 a) was applicable to chemical modification of amino groups in proteins. In this paper, we extended this reaction to aromatization of ( 1 ) in organic solvent to give the corresponding $\mathrm{N}$ arylacetyl derivative ( $3 \mathrm{a}$ ) and carried out normal phase HPLC analysis of ( $3 a)$ to confirm a

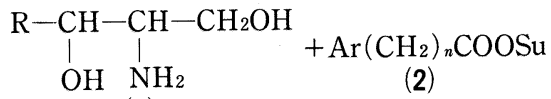

(1)

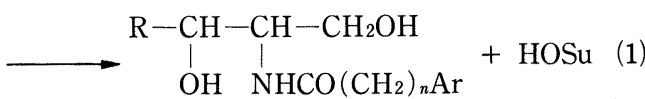

(3)

$\mathrm{Ar}=-\mathrm{C}_{6} \mathrm{H}_{4}-\mathrm{X}$ or $-\mathrm{C}_{6} \mathrm{H}_{3}-\mathrm{X}_{2}$

$\mathrm{R}=n-\mathrm{C}_{9} \mathrm{H}_{19}\left(\mathrm{C}_{12}-\mathrm{DHSph}\right), \quad n-\mathrm{C}_{11} \mathrm{H}_{23}\left(\mathrm{C}_{14}-\mathrm{DHSph}\right)$, $n-\mathrm{C}_{13} \mathrm{H}_{27}\left(\mathrm{C}_{16}-\mathrm{DHSph}\right), \quad n-\mathrm{C}_{15} \mathrm{H}_{31}\left(\mathrm{C}_{16}\right.$-DHSph $)$ $n-\mathrm{C}_{13} \mathrm{H}_{27}-\mathrm{CH}=\mathrm{CH}-\left(\mathrm{C}_{18}-\mathrm{Sph}\right), \quad n-\mathrm{C}_{14} \mathrm{H}_{29}-\mathrm{CH}(\mathrm{OH})-\left(\mathrm{C}_{18}\right.$-Phyto $)$ DHSph : Dihydrosphingosine, Sph : Sphingosine Phyto : Phytosphingosine $\mathrm{Su}=N$-Succinimidyl,

(2a), (3a) $: n=1,(2 \mathrm{~b}),(3 \mathrm{~b}): n=0$

$\mathrm{X}=\mathrm{H}, o-\mathrm{F}, m-\mathrm{F}, p-\mathrm{F}, o-\mathrm{CH}_{3} \mathrm{O}, m-\mathrm{CH}_{3} \mathrm{O}, p-\mathrm{CH}_{3} \mathrm{O}$, $o-\mathrm{Cl}, m-\mathrm{Cl}, p-\mathrm{Cl}, o-\mathrm{Br}, m-\mathrm{Br}, p-\mathrm{Br}, o-\mathrm{NO}_{2}$, $m-\mathrm{NO}_{2}, p-\mathrm{NO}_{2}, o-\mathrm{CH}_{3}, m-\mathrm{CH}_{3}, p-\mathrm{CH}_{3}, p-\mathrm{CN}, p-\mathrm{C}_{2} \mathrm{H}_{5} \mathrm{O}$, 2,4-diNO $2,3,4$-diNO $2,2,4-\mathrm{diCl}$, 3,4-diCl, 2,6-diCl 
sensitive determination of (1). Furthermore, the present method was compared with the previously reported HPLC method with the use of ( 2 b) as the aromatizing reagent and GC method using $\mathrm{N}$-acetyl-O-TMS derivative of (1).

\section{Experiments}

\subsection{Materials}

Phenylacetic and benzoic acid (purity $>97 \%$ ), $\mathrm{DSC}^{* 2}$ and $\mathrm{DSO}^{* 2}$ (SP for peptide synthesis), and 2-nitroethanol (purity : 98\%) were purchased from Aldrich, Tokyo Kasei, Chemiscience, and E. Merck. Freshly distilled aldehydes (RCHO : $\mathrm{R}=n-\mathrm{C}_{9} \mathrm{H}_{19}, n-\mathrm{C}_{11} \mathrm{H}_{23}$, and $n-\mathrm{C}_{13} \mathrm{H}_{27}$; purchased from Tokyo Kasei and Aldrich) were used for the synthesis of $\mathrm{C}_{12^{-}}, \mathrm{C}_{14^{-}}$, and $\mathrm{C}_{16^{-}}$-DHSphs. The other bases $\mathrm{C}_{18}-(1)$, erythro- $\mathrm{C}_{18}-\mathrm{DHSph}{ }^{* 3}, \mathrm{C}_{18}{ }^{-}$ DHSph (a mixture of erythro- and threo- $\mathrm{C}_{18}{ }^{-}$ DHSph), D-erythro- $\mathrm{C}_{18}$-sphingosine ( $\left.\mathrm{Sph}\right)$, and D-ribo- $\mathrm{C}_{18}$ - phytosphingosine (Phyto), were purchased from Sigma.

Hexane and acetonitrile (SP for HPLC analysis) were purchased from Katayama Chemical and the other solvents were purified by the ordinary methods ${ }^{8}$. The TMS reagent (HMDS+ TMCS/pyridine)*2 was purchased from GL Science.

\subsection{Products}

$2 \cdot 2 \cdot 1 \quad \mathrm{~N}$-Succinimidyl arylacetates ( $2 \mathrm{a})$ and benzoates ( $2 \mathrm{~b}$ )

The aromatizing (labeling) reagents having a different substituent in the aromatic ring, ( 2 a) and ( $2 b$ ), were prepared by the coupling reaction of DSC with the corresponding acid in the presence of pyridine in acetonitrile according to the previously reported methods ${ }^{6,9)}$.

\section{$2 \cdot 2 \cdot 2$ Dihydrosphingosine (DHSph)}

2-Amino-1,3-alkanediol (a mixture of erythroand threo- $\mathrm{C}_{n}$-DHSphs : $n=12,14$ and 16$)^{* 3}$ was prepared by the catalytic hydrogenation of the corresponding 2-nitro-1,3-alkanediol according to the previously reported method ${ }^{10)}$. The obtained base was recrystallized from hexane.

* 3 According to "the nomenclature of lipids", recommended by IUPAC - IUB Commission on Biological Nomenclature [Lipids, 12, 455 (1977)], the configuration of naturally occurring $\mathrm{D}-$ erythro- $\mathrm{C}_{18}$ - dihydrosphingosine is shown by $(2 R, 3 S)$. In the present paper, erythro and threo therefore mean mixtures of ( 2 $S, 3 R)+(2 R, 3 S)$ and $(2 R, 3 R)+(2 S, 3 S)$, respectively. threo- and erythro- $\mathrm{C}_{n}$-DHSphs $(n=12,14$ and 16) were prepared by the fractional crystallization of $\mathrm{N}$-acetyl and $\mathrm{N}, \mathrm{O}, \mathrm{O}$-triacetyl derivatives of DHSph, followed by the alkaline hydrolysis ${ }^{11}$.

\subsection{Prepartion of (3) for normal phase HPLC analysis}

A mixture of ( 2 ) (1 2 mg) and (1) (1 $4 \mathrm{mM}, 0.5 \mathrm{~mL}$ ) dissolved in acetonitrile was heated on a hot plate at $50 \sim 60^{\circ} \mathrm{C}$ for $16 \sim 24 \mathrm{~h}$. An aliquot $(0.2 \sim 1 \mu \mathrm{L})$ of the resulting solution was exposed to HPLC analysis.

A mixture (totally: $180 \mathrm{mg}$ ) of $\mathrm{C}_{18}$-DHSph (erythro +threo), D-erythro- $\mathrm{C}_{18}-\mathrm{Sph}$, and $\mathrm{D}-$ ribo$\mathrm{C}_{18}$-Phyto (unknown ratio) was heated in acetonitrile $(300 \mathrm{~mL})$ at $60^{\circ} \mathrm{C}$ for $1 \mathrm{~h}$ and filtered. The filtrate $(0.5 \mathrm{~mL})$ was added to (2) $(1 \mathrm{mg})$ and treated according to the above procedure. The resulting solution was used as a samle for the determination of isomer content of $\mathrm{C}_{18}-(1)$.

\subsection{Analytical methods}

HPLC analysis was carried by the same apparatus in the previous papers ${ }^{6)}$. Column : Inertsil SIL (particle size $: 5 \mu \mathrm{m}$ ), $4.6 \phi \times 250 \mathrm{~mm}$ (GL Science); Mobile phase : $3 \sim 10$ vol\% ethanol/ hexane where $x$ vol\% $a / b$ means solvent $b$ containing $\mathrm{x}$ vol\% of solvent a in this paper; Flow rate $: 1.0 \mathrm{~mL} / \mathrm{min}$; Detection wavelength : $\lambda_{\max }$ of $n-\mathrm{C}_{12} \mathrm{H}_{25} \mathrm{NHCOCH}_{2} \mathrm{Ar}$ and $n-\mathrm{C}_{12} \mathrm{H}_{25}$ NHCOAr ${ }^{(a) \sim 6 c)}$ for ( $3 a$ ) and ( $3 b$ ), respectively. In the case that the amide compounds of dodecylamine did not have $\lambda_{\max }, 220 \mathrm{~nm}$ of the detection wavelength was employed.

UV analysis was done by the same apparatus in the previous paper ${ }^{6 e)}$ at $25^{\circ} \mathrm{C}$. Solvent : the same solvent for HPLC analysis; Light path length : $1 \mathrm{~cm}$.

GC analysis was performed by the Hitachi 26380 Gas Chromatograph (Detector : FID). Column : $1 \%$ Silicone gum SE-30/Gaschrom Q, 80 $\sim 100$ mesh (GL Science), $2 \mathrm{~m}$; Column temperature : $170 \rightarrow 240^{\circ} \mathrm{C}\left(5^{\circ} \mathrm{C} / \mathrm{min}\right), 180 \rightarrow 240^{\circ} \mathrm{C}\left(2^{\circ} \mathrm{C} /\right.$ $\min ), \quad 190 \rightarrow 250^{\circ} \mathrm{C}\left(2^{\circ} \mathrm{C} / \mathrm{min}\right)$, and $200 \rightarrow 270^{\circ} \mathrm{C}$ $\left(2^{\circ} \mathrm{C} / \mathrm{min}\right)$ for $\mathrm{C}_{12}$-DHSphs, $\mathrm{C}_{14}-$ DHSphs, $\mathrm{C}_{16^{-}}$ DHSphs, and $\mathrm{C}_{18}-(1)$, respectively; Flow rate of carrier $(\mathrm{He}): 50 \mathrm{~mL} / \mathrm{min}$.

$\mathrm{N}$-Acetyl-O-TMS derivative of ( 1 ) was prepared as follows: the solvent of substrate solution $(0.5 \mathrm{~mL})$ prior to the aromatization $(2 \cdot 3)$ was removed under a stream of nitrogen and the residue was dried in vacuo for $5 \mathrm{~h}$. The obtained 
crystalline materials were treated with the previously reported method ${ }^{11)}$.

The isomer contents of synthetic DHSph and the mixed $\mathrm{C}_{18}-(1)$ were calculated from the peak areas of the chromatograms in the HPLC and GC analyses.

\section{Results and Discussion}

\subsection{Normal phase HPLC of $\mathrm{C}_{\boldsymbol{n}}$-DHSph in the form of $(3 \mathrm{a})$}

\section{$3 \cdot 1 \cdot 1$ Retention volume}

The amino group of DHSph $\left(\mathrm{C}_{12} \sim \mathrm{C}_{16}\right)$ reacted with ( $2 \mathrm{a}$ ) having a different substituent in the aromatic ring to give the correspoonding $\mathrm{N}$ arylacetyl compounds ( 3 a), whose erythro/threo separation could be accomplished by normal phase using hexane containing ethanol. It was found that the elution order was $\mathrm{C}_{16}-(3 \mathrm{a})>\mathrm{C}_{14}{ }^{-}$ ( $3 a$ a) $>C_{12}-(3 a)$ [where $c>d$ means that compound $c$ is eluted faster than compound $d$ in this paper]. A similar elution order was observed for ( $3 \mathrm{~b})$.

The net retention volumes $\left(V_{N}\right)$ of erythro- and threo- $(3)^{* 4}$ were calculated by the following equation :

$$
V_{N}(3)=V(3)-V(\text { Solvent })
$$

where $V(3)$ and $V$ (Solvent) are the apparent retention volumes of $(3)$ and solvent, respectively. As shown in Table-1, $V_{N}(3 \mathrm{a})$ was comparable with $V_{N}(3 \mathrm{~b})$ in the case of $\mathrm{X}=0-\mathrm{Cl}$. ( 3 a) was less retained than ( 3 b) for $\mathrm{X}=0-\mathrm{NO}_{2}$ and vice versa for the other substituents.

$3 \cdot 1 \cdot 2$ separation factor $(\alpha)$

Next, we calculated the separation factor $(\alpha)$ for normal phase HPLC of ( 3 ), defined by the following equation :

$$
\alpha=\frac{V_{N}[\text { erythro }-(3)]}{V_{N}[\text { threo- }(3)]}
$$

where $V_{N}[$ erythro-( 3$\left.)\right]$ and $V_{N}[$ threo-( 3$\left.)\right]$ are the net retention volumes of erythro- and threo- $\mathrm{C}_{n^{-}}$ DHSphs in the form of (3), respectively. The results are summarized in Table-2, which shows good separation of threo and erythro isomers of DHSphs as ( 3 ). In the case of $(3 a)(X=2,4$ $\operatorname{diNO}_{2}$ ) using $10 \mathrm{vol} \%$ ethanol/hexane, the erythro/threo separation was unsatisfactory, however, it could be accomplished by using 4 vol\% ethanol/hexane as mobile phase.

\begin{tabular}{|c|c|c|c|c|c|c|}
\hline \multirow{2}{*}{$\begin{array}{l}\text { Substituent } \\
\mathrm{X} \text { in (3) }\end{array}$} & \multicolumn{6}{|c|}{$V_{\mathrm{N}}(3 \mathrm{a}) / V_{\mathrm{N}}(3 \mathrm{~b})$} \\
\hline & threo- $C_{12}$ & erythro $-C_{12}$ & threo- $C_{14}$ & erythro $-C_{14}$ & threo- $C_{16}$ & erythro- $C_{16}$ \\
\hline $\mathrm{H}$ & 1.26 & 1.28 & 1.26 & 1.28 & 1.27 & 1.26 \\
\hline$o-\mathrm{F}$ & 1.29 & 1.24 & 1.24 & 1.23 & 1.24 & 1.21 \\
\hline$m-\mathrm{F}$ & 1.36 & 1.37 & 1.33 & 1.36 & 1.32 & 1.32 \\
\hline$p-\mathrm{F}$ & 1.49 & 1.47 & 1.46 & 1.46 & 1.41 & 1.44 \\
\hline $\mathrm{o}-\mathrm{CH}_{3} \mathrm{O}$ & 1.05 & 1.05 & 1.05 & 1.05 & 1.06 & 1.05 \\
\hline$m-\mathrm{CH}_{3} \mathrm{O}$ & 1.30 & 1.34 & 1.26 & 1.32 & 1.28 & 1.32 \\
\hline$p-\mathrm{CH}_{3} \mathrm{O}$ & 1.24 & 1.24 & 1.21 & 1.24 & 1.17 & 1.22 \\
\hline$o-\mathrm{Cl}$ & 1.05 & 1.07 & 1.05 & 1.02 & 1.05 & 1.02 \\
\hline$p-\mathrm{Cl}$ & 1.57 & 1.54 & 1.54 & 1.53 & 1.50 & 1.51 \\
\hline$o-\mathrm{Br}$ & 1.02 & 0.99 & 1.02 & 1.00 & 1.02 & 1.00 \\
\hline$m-\mathrm{Br}$ & 1.40 & 1.41 & 1.38 & 1.39 & 1.39 & 1.36 \\
\hline$p-\mathrm{Br}$ & 1.60 & 1.60 & 1.57 & 1.56 & 1.54 & 1.54 \\
\hline$o-\mathrm{NO}_{2}$ & 0.91 & 0.86 & 0.92 & 0.87 & 0.92 & 0.87 \\
\hline$m-\mathrm{NO}_{2}$ & 1.57 & 1.50 & 1.57 & 1.49 & 1.56 & 1.48 \\
\hline$p-\mathrm{NO}_{2}$ & 2.12 & 2.01 & 2.08 & 1.97 & 2.03 & 1.94 \\
\hline $2,4-\mathrm{diCl}$ & 1.27 & 1.22 & 1.27 & 1.20 & 1.27 & 1.19 \\
\hline $3,4-\mathrm{diCl}$ & 1.66 & 1.63 & 1.61 & 1.60 & 1.58 & 1.58 \\
\hline
\end{tabular}

Table-1 The $V_{N}(3 \mathbf{a}) / V_{N}(3 \mathrm{~b})$ value of synthetic $\mathrm{C}_{n}$-DHSph determined by normal phase HPLC ${ }^{\mathrm{a})}$.

a) Mobile phase : $10 \mathrm{vol} \%$ ethanol/hexane.

* 4 erythro- and threo-( 3 ) are $N$-arylacetyl derivatives of erythro- and threo-( 1 ), respectively. 
Table-2 Separation factor $(\alpha)$ of synthetic $\mathrm{C}_{n^{-}}$ DHSph determined normal phase HPLC in form of $(3)^{a}$.

\begin{tabular}{|c|c|c|c|c|c|c|}
\hline \multirow{3}{*}{$\begin{array}{c}\text { Substituent } \\
\mathrm{X} \text { in }(3)\end{array}$} & \multicolumn{6}{|c|}{ Separation factor $(\alpha)$} \\
\hline & \multicolumn{2}{|c|}{$\mathrm{C}_{12}-\mathrm{DHSph}$} & \multicolumn{2}{|c|}{$\mathrm{C}_{14}-\mathrm{DHSph}$} & \multicolumn{2}{|c|}{$\mathrm{C}_{16}-$ DHSph } \\
\hline & (3a) & $(3 \mathrm{~b})$ & $(3 \mathbf{a})$ & $(3 \mathbf{b})$ & $(3 \mathrm{a})$ & $(3 \mathrm{~b})$ \\
\hline $\mathrm{H}$ & 1.23 & 1.33 & 1.21 & 1.33 & 1.18 & 1.33 \\
\hline$o-\mathrm{F}$ & 1.22 & 1.37 & 1.20 & 1.37 & 1.18 & 1.37 \\
\hline$m-\mathrm{F}$ & 1.23 & 1.29 & 1.27 & 1.30 & 1.25 & 1.29 \\
\hline$p-\mathrm{F}$ & 1.21 & 1.31 & 1.22 & 1.31 & 1.26 & 1.31 \\
\hline $\mathrm{O}-\mathrm{CH}_{3} \mathrm{O}$ & 1.39 & 1.42 & 1.38 & 1.40 & 1.35 & 1.39 \\
\hline$m-\mathrm{CH}_{3} \mathrm{O}$ & 1.29 & 1.30 & 1.33 & 1.29 & 1.33 & 1.32 \\
\hline$p-\mathrm{CH}_{3} \mathrm{O}$ & 1.28 & 1.32 & 1.31 & 1.30 & 1.36 & 1.31 \\
\hline$O-\mathrm{Cl}$ & 1.30 & 1.38 & 1.29 & 1.37 & 1.27 & 1.36 \\
\hline$m-\mathrm{Cl}$ & - & 1.29 & - & 1.29 & - & 1.30 \\
\hline$p-\mathrm{Cl}$ & 1.20 & 1.33 & 1.21 & 1.33 & 1.24 & 1.34 \\
\hline$o-\mathrm{Br}$ & 1.31 & 1.37 & 1.29 & 1.36 & 1.28 & 1.33 \\
\hline$m-\mathrm{Br}$ & 1.23 & 1.30 & 1.22 & 1.29 & 1.19 & 1.31 \\
\hline$p-\mathrm{Br}$ & 1.20 & 1.33 & 1.20 & 1.33 & 1.22 & 1.38 \\
\hline$o-\mathrm{NO}_{2}$ & 1.17 & 1.25 & 1.17 & 1.25 & 1.17 & 1.25 \\
\hline$m-\mathrm{NO}_{2}$ & 1.09 & 1.19 & 1.09 & 1.20 & 1.09 & 1.20 \\
\hline$p-\mathrm{NO}_{2}$ & 1.08 & 1.21 & 1.08 & 1.21 & 1.07 & 1.21 \\
\hline$p-\mathrm{C}_{2} \mathrm{H}_{5} \mathrm{O}$ & 1.29 & - & 1.30 & - & 1.28 & - \\
\hline$o-\mathrm{CH}_{3}$ & - & 1.33 & - & 1.33 & - & 1.33 \\
\hline$m-\mathrm{CH}_{3}$ & - & 1.34 & - & 1.35 & - & 1.35 \\
\hline$p-\mathrm{CH}_{3}$ & - & 1.35 & - & 1.36 & - & 1.36 \\
\hline$p-\mathrm{CN}$ & - & 1.21 & - & 1.22 & - & 1.25 \\
\hline $2,4-\mathrm{diNO}_{2}$ & $1.07^{\mathrm{b})}$ & 1.18 & $1.07^{\mathrm{b})}$ & 1.18 & $1.04^{\mathrm{b})}$ & 1.18 \\
\hline $3,4-\mathrm{diNO}_{2}$ & - & $0.92^{c}$ & - & $0.92^{c)}$ & - & $0.92^{c}$ \\
\hline $2,4-\mathrm{diCl}$ & 1.24 & 1.38 & 1.21 & 1.40 & 1.19 & 1.41 \\
\hline $3,4-\mathrm{diCl}$ & 1.16 & 1.30 & 1.18 & 1.31 & 1.18 & 1.31 \\
\hline $2,6-\mathrm{diCl}$ & 1.33 & - & 1.33 & - & 1.33 & - \\
\hline
\end{tabular}

a) Mobile phase : $10 \mathrm{vol} \%$ ethanol/hexane. Detection wavelength : see Table-3.

b) Mobile phase : 4 vol\% ethanol/hexane.

c) Mobile phase : 30 vol\% ethanol/hexane.

Table-2 also shows that a variety of substituents $(\mathrm{X})$ could be applicable to the analysis. The threo isomer of synthetic DHSph was eluted faster than its erythro one except (3 b) ( $\mathrm{X}=3,4$ $\operatorname{diNO}_{2}$ ). It is reported that the elution order of erythro $>$ threo is observed for $\mathrm{N}$-acetyl DHSph and vice versa for $\mathrm{N}, \mathrm{O}, \mathrm{O}$-triacetyl derivative of DHSph in normal phase HPLC ${ }^{4}$. It is also reported that threo- $(3 \mathrm{~b})$ retained more strongly than erythro- $(3 \mathrm{~b})$ in reverse phase HPLC be-

*5 $\alpha^{-1}$ was 1.09 for $(3 b)\left(X=3,4-\operatorname{diNO}_{2}\right)$. cause the aromatic ring in ( $3 \mathrm{~b}$ ) would interact with the reverse phase $\left(\mathrm{C}_{18}\right)^{6 c)}$.

The $\alpha$ values were $1.08 \sim 1.39\left(\mathrm{C}_{12}-\mathrm{DHSph}\right)$, $1.08 \sim 1.38\left(\mathrm{C}_{14}-\mathrm{DHSph}\right)$, and $1.07 \sim 1.36\left(\mathrm{C}_{16}{ }^{-}\right.$ DHSph), as ( $3 \mathrm{a})$ and 1. 18 1.42 ( $\mathrm{C}_{12}$-DHSph), $1.18 \sim 1.40\left(\mathrm{C}_{14}-\mathrm{DHSph}\right)$, and $1.18 \sim 1.39\left(\mathrm{C}_{16}{ }^{-}\right.$ DHSph) as $(3 b)^{* 5}$. The $\alpha$ value of ( $3 a$ ) was same as that of $(3 b)$ in the case of $X=$ methoxy $\left(\mathrm{CH}_{3} \mathrm{O}\right)$, however, the former was smaller than the latter for the other substituents.

$3 \cdot 1 \cdot 3$ Determination of threo content of synthetic $\mathrm{C}_{n}$-DHSph

Based on the above findings, the threo content of synthetic $\mathrm{C}_{n}$-DHSph was determined in the form of ( $3 \mathrm{a}$ ) and compared with those determined by normal phase HPLC in the form of ( 3 b) and GC using $\mathrm{N}$-acetyl-O, $\mathrm{O}$-bis (TMS) derivative of DHSph. As shown in Table-3, an excellent coincidence was observed between the HPLC and GC methods.

\section{$3 \cdot 2$ Normal phase HPLC of $\mathrm{C}_{18}-(1)$}

\section{$3 \cdot 2 \cdot 1$ Separation}

We applied the present method using ( $2 a$ ) as the aromatizing reagent to the determination of naturally occurring sphingolipid bases, $\mathrm{C}_{18}-(1)$. The analysis was carried out using commercially available bases (see $2 \cdot 1$ and $2 \cdot 3$ ).

The ratio, $V_{N}(3) / V_{N}(2)$ [where $V_{N}(2)$ and $V_{N}(3)$ are the net retentiion volumes of ( 2 ) and (1) as (3), respectively], was calculated to clarify the elution order of (1). As shown in Table-4, a good separation of ( 1 ) was obtained except for ( $3 \mathrm{a})\left(\mathrm{X}=m\right.$ - and $\left.p-\mathrm{NO}_{2}\right)$ and $\mathrm{C}_{18^{-}}$ (1) was eluted in the order of threo- $\mathrm{C}_{18}-\mathrm{DHSph}$ > erythro- $\mathrm{C}_{18}-\mathrm{DHSph}>\mathrm{D}-$ erythro- $\mathrm{C}_{18}-\mathrm{Sph}>\mathrm{D}-$ ribo- $\mathrm{C}_{18}$-Phyto (with an exception of $\mathrm{D}$-erythro$\mathrm{C}_{18}-\mathrm{Sph}>$ erythro- $\mathrm{C}_{18}-\mathrm{DHSph}$ for $\mathrm{X}=0-\mathrm{NO}_{2}$ ).

$3 \cdot 2 \cdot 2$ Determination of isomer content of $\mathrm{C}_{18^{-}}$ (1)

Finally, we measured the isomer content of the mixed sample $(2 \cdot 3)$ to verify the sensitive determination of $(1)$. The results are summarized in Table-5, which shows good agreement between the HPLC method in the form of ( 3 ) having a different substituent in the aromatic ring and the GC method using $\mathrm{N}$-acetyl-O-TMS derivative of (1).

From the above observations, we concluded that ( $2 a)$ was applicable as the aromatization reagent for the determination of ( 1 ) by normal 
Table-3 The threo contents of synthetic $\mathrm{C}_{n}$-DHSph determined by normal phase HPLC in the form of $(3)$ and GC in the form of $\mathrm{N}$-acetyl-O, O-bis(TMS) derivative of $\mathrm{C}_{n}$ - $\mathrm{DHSph}^{\mathrm{a})}$.

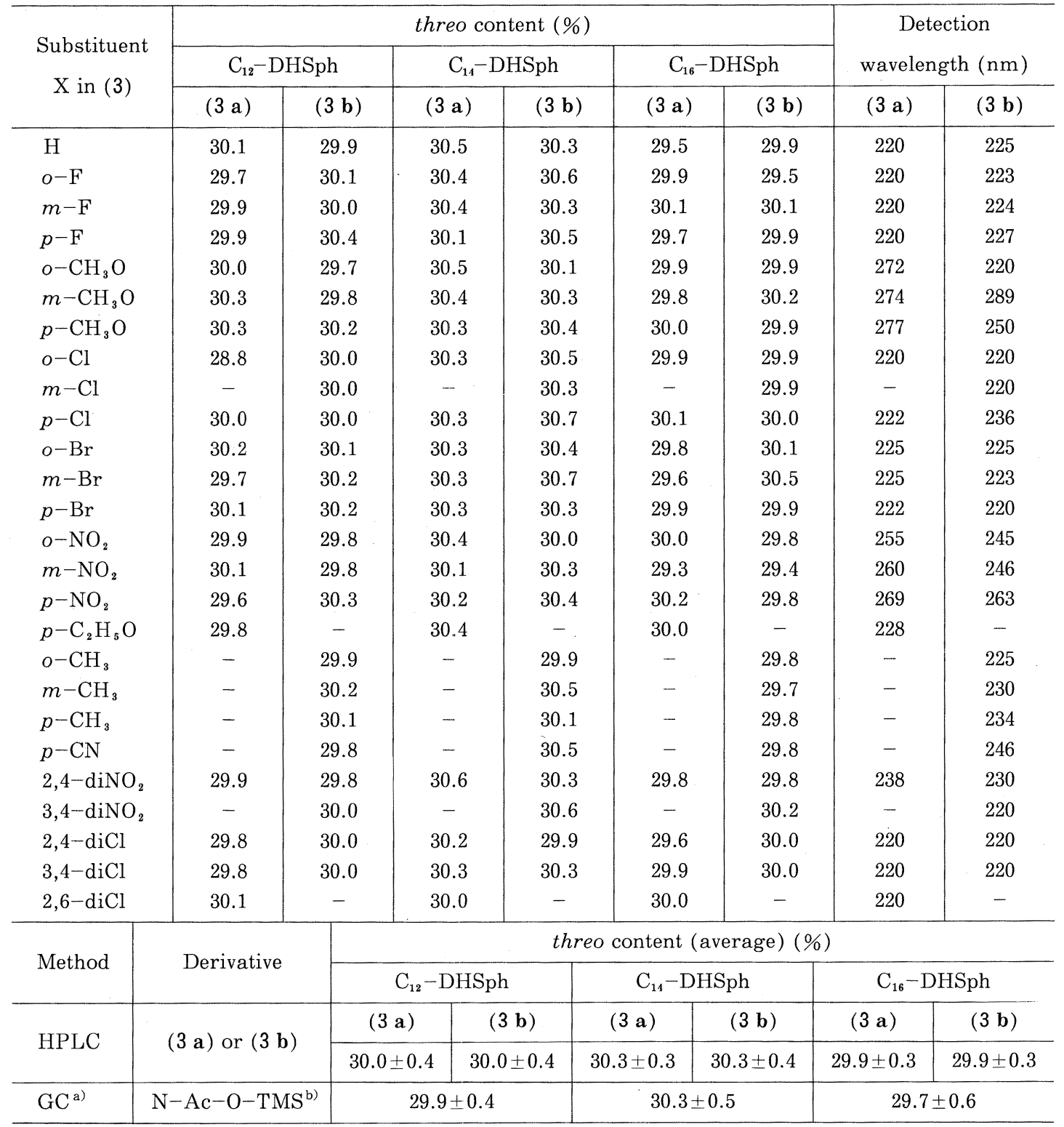

a) Average of $5 \sim 10$ runs.

b) $N$-Acetyl-O,O-bis(TMS) derivative of $\mathrm{C}_{n}$-DHSph. 
Table-4 The ratio, $V_{N}(3) / V_{N}(2)$, of $\mathrm{C}_{18}-(1)$ as $(3)$ determined normal phase HPLC ${ }^{\mathrm{a}}$.

\begin{tabular}{|c|c|c|c|c|c|}
\hline \multirow{2}{*}{$\begin{array}{c}\text { Derivative } \\
\text { (3) }\end{array}$} & \multirow{2}{*}{$\begin{array}{l}\mathrm{C}_{18}-(1) \\
\mathrm{X} \text { in }(3)\end{array}$} & \multicolumn{4}{|c|}{$V_{\mathrm{N}}(3) / V_{\mathrm{N}}(2)$} \\
\hline & & threo-DHSph & erythro-DHSph & $\mathrm{D}-$ erythro-Sph & $\mathrm{D}-$ ribo-Phyto \\
\hline$(3 \mathrm{a})$ & $\begin{array}{l}p-\mathrm{CH}_{3} \mathrm{O} \\
p-\mathrm{C}_{2} \mathrm{H}_{5} \mathrm{O} \\
p-\mathrm{Cl} \\
p-\mathrm{Br} \\
o-\mathrm{NO}_{2} \\
m-\mathrm{NO}_{2} \\
p-\mathrm{NO}_{2}\end{array}$ & $\begin{array}{c}0.64 \\
0.64[1.34] \\
0.70[1.49] \\
0.71[1.52] \\
0.56 \\
0.66 \\
0.81\end{array}$ & $\begin{array}{c}0.86 \\
0.87[1.99] \\
0.89[2.00] \\
0.89[2.02] \\
0.69 \\
0.74 \\
0.89\end{array}$ & $\begin{array}{c}0.92 \\
0.94[2.18] \\
0.95[2.15] \\
0.95[2.18] \\
0.61 \\
0.76 \\
0.91\end{array}$ & $\begin{array}{c}1.36 \\
1.35[3.48] \\
1.48[3.79] \\
1.48[3.84] \\
1.08 \\
1.23 \\
1.56\end{array}$ \\
\hline$(3 \mathrm{~b})$ & $\begin{array}{l}\mathrm{H} \\
o-\mathrm{F} \\
m-\mathrm{F} \\
p-\mathrm{F} \\
m-\mathrm{CH}_{3} \\
p-\mathrm{CH}_{3} \\
p-\mathrm{CH}_{3} \mathrm{O} \\
p-\mathrm{Cl} \\
p-\mathrm{Br} \\
o-\mathrm{NO}_{2} \\
m-\mathrm{NO}_{2} \\
p-\mathrm{NO}_{2}\end{array}$ & $\begin{array}{cl}0.35 & (0.32) \\
0.28 \\
0.33 & (0.31) \\
0.33 & (0.30) \\
0.33 \\
0.34 \\
0.28(0.34) \\
0.31(0.28) \\
0.30(0.28) \\
0.55 \\
0.38(0.33) \\
0.34(0.32)\end{array}$ & $\begin{array}{cl}0.48 & (0.44) \\
0.41 \\
0.46(0.41) \\
0.45(0.41) \\
0.47 \\
0.47 \\
0.50(0.44) \\
0.44(0.39) \\
0.43(0.38) \\
0.72 \\
0.48(0.42) \\
0.45(0.38)\end{array}$ & $\begin{array}{cl}0.58 & (0.51) \\
0.47 \\
0.54(0.49) \\
0.55(0.49) \\
0.58 \\
0.58 \\
0.58(0.52) \\
0.54(0.49) \\
0.54(0.48) \\
0.62 \\
0.54(0.48) \\
0.55(0.48)\end{array}$ & $\begin{array}{c}0.86(0.73) \\
0.61 \\
0.82(0.68) \\
0.84(0.69) \\
0.81 \\
0.82 \\
0.94(0.79) \\
0.78(0.61) \\
0.76(0.60) \\
1.22 \\
0.90(0.77) \\
0.83(0.70)\end{array}$ \\
\hline
\end{tabular}

a) Mobile phase : $7 \mathrm{vol} \%$ ethanol/hexane. The numbers in the brackets and parentheses are the $V_{\mathrm{N}}(3)$ $/ V_{\mathrm{N}}(2)$ values determined using 3.0 and $8.5 \mathrm{vol} \%$ ethanol/hexane, respectively.

Table-5 The isomer contents of the mixed sample $(2 \cdot 3)$ determined by normal phase HPLC in the form of $(3)$ and $\mathrm{GC}$ in the form of $\mathrm{N}$-acetyl-O-TMS derivative of ( 1 ).

\begin{tabular}{|c|c|c|c|c|c|}
\hline \multirow{2}{*}{$\begin{array}{c}\text { Derivative } \\
\text { (3) }\end{array}$} & \multirow{2}{*}{$\frac{\mathrm{C}_{18}-(1)}{\mathrm{X} \text { in }(3)}$} & \multicolumn{4}{|c|}{ Content (\%) } \\
\hline & & threo-DHSph & erythro-DHSph & $\mathrm{D}-$ erythro-Sph & $\mathrm{D}-$ ribo-Phyto \\
\hline$(3 a)^{d)}$ & $\begin{array}{l}p-\mathrm{CH}_{3} \mathrm{O}^{\mathrm{a})} \\
p-\mathrm{C}_{2} \mathrm{H}_{5} \mathrm{O}^{\mathrm{b})} \\
p-\mathrm{Cl}^{\mathrm{b})} \\
p-\mathrm{Br}^{\mathrm{a})} \\
o-\mathrm{NO}_{2}{ }^{\mathrm{a})}\end{array}$ & $\begin{array}{l}24.2 \\
23.7 \\
24.0 \\
24.4 \\
25.5\end{array}$ & $\begin{array}{l}22.7 \\
21.4 \\
21.6 \\
21.4 \\
21.0\end{array}$ & $\begin{array}{l}21.0 \\
20.8 \\
21.1 \\
20.5 \\
20.7\end{array}$ & $\begin{array}{l}32.1 \\
34.1 \\
33.3 \\
33.6 \\
32.9\end{array}$ \\
\hline$(3 \mathrm{~b})$ & $\begin{array}{l}\mathrm{H}^{\mathrm{c})} \\
o-\mathrm{F}^{\mathrm{a})} \\
m-\mathrm{F}^{\mathrm{c})} \\
p-\mathrm{F}^{\mathrm{c})} \\
m-\mathrm{CH}_{3}{ }^{\mathrm{a})} \\
p-\mathrm{CH}_{3}{ }^{\mathrm{a})} \\
p-\mathrm{CH}_{3} \mathrm{O}^{\mathrm{c})} \\
p-\mathrm{Cl}^{\mathrm{c})} \\
p-\mathrm{Br}^{\mathrm{c})} \\
o-\mathrm{NO}_{2}{ }^{\mathrm{c})} \\
m-\mathrm{NO}_{2}{ }^{\mathrm{c})} \\
p-\mathrm{NO}_{2}{ }^{\mathrm{c})}\end{array}$ & $\begin{array}{l}23.9 \\
23.4 \\
24.5 \\
24.7 \\
24.3 \\
24.6 \\
23.8 \\
25.2 \\
25.1 \\
25.3 \\
25.4 \\
24.0\end{array}$ & $\begin{array}{l}21.7 \\
22.5 \\
21.6 \\
21.8 \\
21.9 \\
21.7 \\
22.2 \\
21.7 \\
21.3 \\
21.8 \\
21.9 \\
21.7\end{array}$ & $\begin{array}{l}21.2 \\
21.1 \\
21.3 \\
20.9 \\
20.3 \\
20.9 \\
20.9 \\
20.5 \\
20.9 \\
20.0 \\
20.9 \\
21.6\end{array}$ & $\begin{array}{l}33.2 \\
33.1 \\
32.7 \\
32.6 \\
33.5 \\
33.1 \\
33.4 \\
32.4 \\
32.7 \\
32.9 \\
31.8 \\
32.9\end{array}$ \\
\hline Method & Derivative & \multicolumn{4}{|c|}{ Content (average) (\%) } \\
\hline \multirow{2}{*}{ HPLC } & $(3 \mathbf{a})$ & $24.4 \pm 1.4$ & $21.6 \pm 1.1$ & $20.8 \pm 0.3$ & $33.2 \pm 1.1$ \\
\hline & $(3 \mathbf{b})$ & $24.5 \pm 1.1$ & $21.8 \pm 0.7$ & $20.8 \pm 0.8$ & $32.8 \pm 1.0$ \\
\hline $\mathrm{GC}^{\mathrm{e})}$ & $N-\mathrm{Ac}-O-\mathrm{TMS}$ & $24.5 \pm 0.6$ & $21.7 \pm 0.5$ & $21.0 \pm 0.4$ & $32.8 \pm 0.7$ \\
\hline
\end{tabular}

a) Mobile phase : $7 \mathrm{vol} \%$ ethanol/hexane. b) Mobile phase : 3 vol\% ethanol/hexane.

c) Mobile phase : $8.5 \mathrm{vol} \%$ ethanol/hexane. d) The baseline separation was not obtained between erythro-DHSph and $\mathrm{D}$-erythro-Sph for $\mathrm{X}=m-\mathrm{NO}_{2}$ and $p-\mathrm{NO}_{2}$.

e) Average of five runs. 
phase HPLC

A part of this work has been reported at the 29th Annual Meeting of the Japan Oil Chemists' Society (1990) Sendai.

(Received May 30, 1991)

\section{References}

1) a) R. C. Gaver and C.C. Sweeley, J.Am. Chem. Soc. , 88, 3643 (1966) ; b) H. E. Carter and R. C. Gaver, J. Lipid Res., 8, 391 (1967); c) J. A. Polito, T. Akita, and C. C. Sweeley, Biochemistry, 7, 2609 (1968); d) A. Kuksis, Fette, Seifen, Anstrichm., 75, 317 (1973).

2) a) H. Hirata, Yukagaku, 29, 2(1980);b) H. Hirata, S. Nakasato, and T. Shimada, Yukaga$k u, \quad 29, \quad 572(1980)$; c) T. Yamashina, K. Higuchi, and H. Hirata, Kagikenho (J. Natl. Chem. Lab. Ind.), 81, 317 (1986).

3) a) H. Hirata, Yukagaku, 33, 12 (1984) ; b) H. Hirata, A. Kisic, J.S. Brabson, and G. J. Schroepfer, Jr., Yukagaku, 34, 178 (1985).

4) K. Higuchi, T. Yamashina, and H. Hirata, $J$. Jpn. Oil Chem. Soc. (Yukagaku), 37, 422 (1988).

5) H. Hirata and S. Nakasato, Yukagaku, 32, 754 (1983).

6) a) T. Yamashina, K. Higuchi, and H. Hirata, J. Jpn. Oil Chem. Soc. (Yukagaku), 37, 349 (1988) ; b) T. Yamashina, K. Higuchi, and H. Hirata, ibid., 37, $1143(1988)$; c) T. Yamashina, K. Higuchi, and H. Hirata, ibid., 38, 280 (1989) ; d) K. Higuchi, T. Yamashina, and H. Hirata, Proc. ISF-JOCS World Congress 1988 (1989) Vol. II , p. 950 ; e) K. Higuchi, T. Yamashina, and H. Hirata, J. Jpn. Oil Chem. Soc. (Yukagaku), 38, 923 (1989).

7) a) H. Hirata, T. Yamashina, and K. Higuchi, J. Jpn. Oil Chem. Soc. (Yukagaku), 38, 608(1989) ; b) H. Hirata, T. Yamashina, and K. Higuchi, J. Jpn. Oil Chem. Soc. (Yukagaku), 40, 406 (1991).
8) J.A. Riddick and W.B. Bunger, "Organic Solvents", Wiley-Interscience, New York, London, Sydney, Toronto (1970) IV, p. 552.

9) a) K. Higuchi, T. Yamashina, K. Ishikawa, and H. Hirata, J. Jpn. Oil Chem. Soc. (Yukagaku), 36, $16(1987)$; b) T. Yamashina, K. Higuchi, and H. Hirata, J. Jpn. Oil Chem. Soc. (Yukagaku) , 40, 155 (1991).

10) H. Hirata, S. Nakasato, K. Higuchi, M. Okimura, and T. Shimada, Yukagaku, 29, 336 (1980).

11) H. Hirata, K. Higuchi, S. Nakasato, and G. J. Schroepfer, Jr., J. Jpn. Oil Chem. Soc. (Yukagaku), 35, 18 (1986).

スクシンイミドエステルの化学 (第 21 報)

$N$-アリールアセチル誘導体を用いたスフィンゴ 塩基の順相 HPLC による定量

\author{
平田博文・樋口勝彦・山科孝雄・杉浦正昭 \\ 工業技術院 化学技術研究所 \\ （テ305つくば市東 1-1）
}

スフィンゴ塩基（1）の高感度定量法の確立を目的と して, 基質として合成したジヒドロスフィンゴシンと $\mathrm{C}_{18}$ - (1) を, 芳香 (ラベル) 化剤として $N$-スクシン イミジルアリールアセテート（2a）を用いて, 順相 HPLC 分析の検討を行った。（1）のアミノ基は（2a) と容易に反応して相当する $N$-アリールアセチル化合 物（3a）を生成した。（1）の異性体は（3a）の形に するとUV 領域に吸収を持つようになり，しかも，種々 の置換基を持つ（3a）形で順相 HPLC で分離ができ ることがわかった。また，順相 HPLC 分析から求めた （1）の異性体の組成が従来知られている（1）のNアセチル-O-TMS 体のGC分析及び（1）の $N$-アリルカルボニル体, (3 b), の順相 HPLC の結果と良好 な一致を示すことを認めた。 